University of Nebraska - Lincoln

DigitalCommons@University of Nebraska - Lincoln

Faculty Publications: Department of Entomology

Entomology, Department of

April 1997

\title{
Effects of Alachlor on an Algal Community from a Midwestern Agricultural Stream
}

\author{
Rebecca Spawn \\ University of Nebraska-Lincoln \\ Kyle D. Hoagland \\ University of Nebraska-Lincoln, khoagland1@unl.edu \\ Blair Siegfried \\ University of Nebraska-Lincoln, bsiegfried1@ufl.edu
}

Follow this and additional works at: https://digitalcommons.unl.edu/entomologyfacpub

Part of the Entomology Commons

Spawn, Rebecca; Hoagland, Kyle D.; and Siegfried, Blair, "Effects of Alachlor on an Algal Community from a Midwestern Agricultural Stream" (1997). Faculty Publications: Department of Entomology. 133.

https://digitalcommons.unl.edu/entomologyfacpub/133

This Article is brought to you for free and open access by the Entomology, Department of at DigitalCommons@University of Nebraska - Lincoln. It has been accepted for inclusion in Faculty Publications: Department of Entomology by an authorized administrator of DigitalCommons@University of Nebraska - Lincoln. 


\title{
Effects of Alachlor on an Algal Community from a Midwestern Agricultural Stream
}

\author{
Rebecca L. Spawn, Kyle D. Hoagland*, and Blair D. Siegfried \\ Department of Forestry, Fisheries and Wildlife, 101 Plant Industry, University of Nebraska-Lincoln, Lincoln, Nebraska 68583, USA \\ * Corresponding author.
}

\begin{abstract}
The effects of a single pulse, 21-d exposure of the commonly used herbicide alachlor (2-chloro-2', 6'-diethyl- $N$-methoxymethyl acetanilide) on an algal community from a typical agricultural stream in Nebraska were studied using 18 stream microcosms located in a greenhouse, at six alachlor concentrations $(0,1,10,30,100$, and $1,000 \mu \mathrm{g} / \mathrm{L})$. Effects of alachlor exposure at $1.0 \mu \mathrm{g} / \mathrm{L}$ were not significant $(p<0.05)$; however, at all other concentrations, alachlor had a significant negative effect on algal biomass. Differential taxonomic responses were observed, with approximately half the dominant algal taxa affected at levels $>10 \mu \mathrm{g} / \mathrm{L}$. Some taxa recovered from exposure by day 7 , while others took longer or did not recover. A shift in the dominant algae was observed at higher concentrations $(30,100,1,000 \mu \mathrm{g} / \mathrm{L})$, and after $21 \mathrm{~d}$ these streams exhibited total algal cell densities significantly lower than the control and $1.0-\mu \mathrm{g} / \mathrm{L}-$ level streams. Results of this study suggest that alachlor inputs can alter both algal community composition and biomass in agricultural streams. Consequently, potential indirect impacts of alachlor on higher trophic levels warrant further investigation.
\end{abstract}

Keywords: Alachlor, Algae, Artificial streams, Herbicides, Toxicity

\section{INTRODUCTION}

The use of pesticides by modern agriculture has increased dramatically in the recent past [1]. It is well known that pesticide levels in streams draining agricultural lands can reach relatively high levels during spring storm runoff events [2,3]. Because of their inherent toxicity, and because pesticides such as alachlor (Lasso®) can enter streams via agricultural runoff, their use may involve considerable risk to nontarget aquatic organisms [4]. Alachlor has been the most heavily used pesticide in the United States [5], with annual applications exceeding five million pounds in Nebraska alone [5]. Of the 149 midwestern U.S. stream sites surveyed, alachlor was detected in $86 \%$ of the samples [6]. Despite its widespread use, few studies have specifically addressed the effects of alachlor on freshwater algae [7].

Alachlor is a chloroacetamide preemergent herbicide applied to corn, soybean, and sorghum crops to control weed grasses [4]. Although chloroacetamide herbicides have been used for over 30 years, their primary mode of action is not fully understood [8,9]. Chloroacetamides interfere with metabolism, inhibit cell division and uptake of minerals, decrease enzyme activity, and inhibit synthesis of proteins, lipids, epicuticular waxes, and fatty acids [9]. Alachlor has been found to cause intracellular membrane damage and is thought to interfere with starch mobilization and lipid synthesis in sorghum [10]. Herbicides such as alachlor and atrazine can inhibit algal growth and photosynthesis at concentrations less than $0.1 \mu \mathrm{g} / \mathrm{L}[11]$ or $1.0 \mu \mathrm{g} / \mathrm{L}$ [12], respectively. Alachlor concentrations as high as 105 $\mu \mathrm{g} / \mathrm{L}$ have been found in streams in the Midwest [13].

To date, very few studies have focused specifically on the effects of alachlor on freshwater algae, and none have been conducted on algae from lotic systems, rather in small laboratory containers. Singh et al. [14] investigated the effects of alachlor on various strains of the blue-green Nostoc muscorum C.A. Ag. and found alachlor to be significantly both growth-inhibiting and mutagenic. Weisshaar et al. [8] and Couderchet and Boger [9] investigated the influence of alachlor and metazachlor on fatty acid synthesis of the green alga Scenedesmus acutus and found significant negative effects. Krieger et al. [15] found that a mixture of four herbicides including alachlor (mean concentration $=35 \mu \mathrm{g}$ / L) inhibited attached algal biomass by $45 \%$ at $10^{\circ} \mathrm{C}$ and $19 \%$ at $25^{\circ} \mathrm{C}$ in artificial streams.

Pesticides have been found at their highest levels when heavy rains occur soon after field application $[15,16]$. However, because some pesticides such as alachlor readily adsorb to soil, an accurate determination of pesticide impacts cannot be made based on water column concentrations alone [17]. Pesticide effects on the organisms that attach to available substrata, such as epipelic algae, also need to be taken into account when analyzing pesticide effects on aquatic ecosystems. Epipelic algae reproduce, photosynthesize, and take up nutrients within the benthos $[18,19]$, hence it can be assumed that these algae are directly exposed to dissolved and sediment-bound toxins. Due to the essential role they play as the most prevalent primary producers in many midwestern lotic environments, algal responses to pesticides are important because they form the base of the food web and affect higher trophic levels. Thus, the objective of this study was to examine the effects of alachlor on an algal community from a typical midwestern stream draining agricultural lands. We used artificial stream microcosms to allow for a robust experimental design and acute exposures to alachlor to simulate rapid inputs of the herbicide characteristic of surface runoff during spring storms.

\section{MATERIALS AND METHODS}

\section{Artificial streams}

Artificial streams were constructed to facilitate use of more complex experimental designs while providing a realistic simula- 


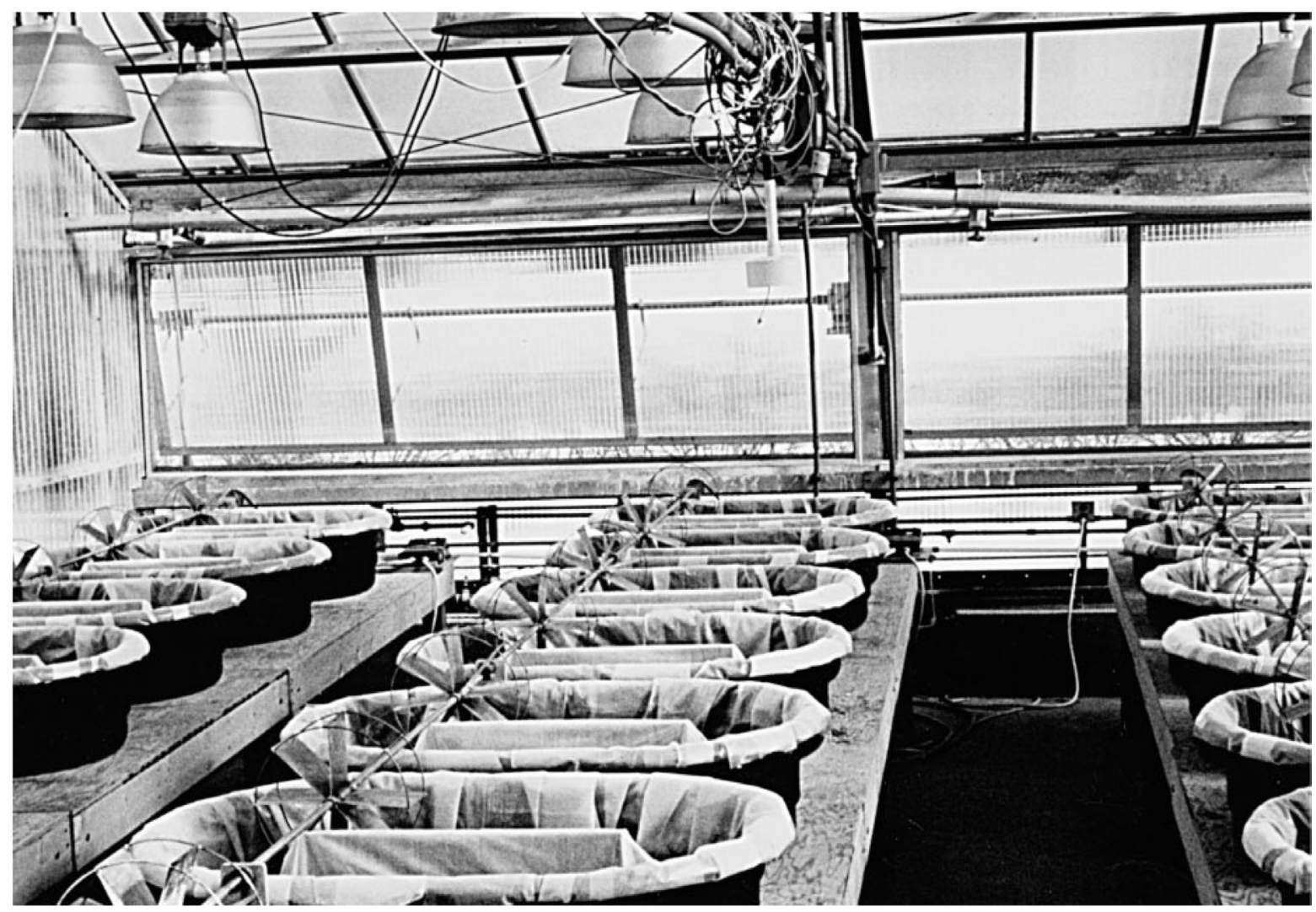

Figure 1. Artificial streams, housed in a greenhouse at the University of Nebraska-Lincoln.

tion of a lotic environment. Streams were constructed from 175-L high-density polyethylene stock tanks $(120 \mathrm{~cm}$ long $\times 75 \mathrm{~cm}$ wide $\times 30 \mathrm{~cm}$ deep). A plywood divider was placed in the center of each tank to create an oval channel. Streams were arranged on tables in blocks of eight, with water current in each bank of eight streams driven by a single DC motor (model 1324-MB61-EC17) with a stainless steel shaft and eight paddle-wheels (Precision Machine Inc., Lincoln, NE, USA) (Figure 1). A total of 18 streams (six concentrations $\times$ three replicates) were housed in a greenhouse on the University of Nebraska campus. Natural illumination was supplemented with 1,000-W metalarc lamps suspended $6 \mathrm{~m}$ above the streams (mean photon flux density $=189 \pm 9 \mu \mathrm{mol} / \mathrm{m}^{2} / \mathrm{s}$ at the onset of the experiment), set on a 12:12 light:dark cycle. The greenhouse temperature was set at a constant $10^{\circ} \mathrm{C}$. To prevent tank contamination, the stream tanks were lined with 4 -mil plastic. The bottoms of the streams were covered with $20 \times 20$-cm unglazed baked clay tiles to provide a uniform flat surface. On top of the $20-\mathrm{cm}$ square tiles were placed $5 \times 5$-cm unglazed baked clay tiles to be used as artificial substrata for collecting attached algae, thus providing a uniform sample unit and surface area. Research has shown that unglazed baked clay tiles are a suitable artificial substrate for benthic algal development [20]. Natural stream water obtained from Bear Creek, located $3.2 \mathrm{~km}$ east of Beatrice, Nebraska was chosen because it is typical of streams in eastern Nebraska draining agricultural land. Preliminary analysis of Bear Creek water at base flow showed no detectable background levels of alachlor and only trace amounts $(0.008 \mu \mathrm{g} / \mathrm{L})$ of the herbicide atrazine. No other pesticides were detected in water from Bear Creek.

Tanks were filled on November 20, 1992, by first pumping Bear Creek water directly into a 3,800-L polyethylene tank using a Honda centrifugal pump and fire hose. The intake water was fil- tered to exclude only fish and large debris. Water was returned to the laboratory and dispensed into each artificial stream using a submersible pump. The tanks were filled with $114 \mathrm{~L}$ of water in 38-L intervals to create maximum uniformity in the algal flora in all streams. Streams were maintained at a constant current velocity of $15 \pm 2 \mathrm{~cm} / \mathrm{s}$.

Algae were allowed to colonize tiles for 4 weeks prior to herbicide introduction. Beginning 1 week after water addition, streams were supplemented with nitrogen (as ammonium chloride) and phosphorus (as potassium phosphate) at a rate of 0.076 $\mathrm{g}$ and $0.016 \mathrm{~g}$, respectively (ca. 10\% of initial ambient stream concentrations), every other day, to prevent nutrient depletion. Approximately $3 \mathrm{~L}$ of water were lost daily from each tank due to evaporation. Consequently, for the first 2 weeks of the colonization period, $1 \mathrm{~L}$ was replaced with Bear Creek stream water stored in unused, circulated streams, and $2 \mathrm{~L}$ were replaced with distilled water daily. For the remaining 2 weeks of colonization and after pesticide addition, water loss due to evaporation was replaced with distilled water only, to avoid increases in dissolved salts.

\section{Sampling procedures}

Thirty days after filling tanks, pretreatment samples of algae and water were taken. Water samples were analyzed for total nitrogen and total phosphorus [21], turbidity (model 2100A turbidimeter, Hach, Loveland, CO, USA), pH (Orion, model SA520, Boston, MA, USA), dissolved oxygen (YSI, model 57, Yellow Springs, $\mathrm{OH}, \mathrm{USA}$ ), and temperature (YSI, model 43TD, Yellow Springs, OH, USA). Light intensity was also recorded (LiCor, model 192S, Lincoln, NE, USA). Water samples were collected by dipping 1- 
Table 1. Alachlor concentrations in the water column and chlorophyll $a$ at all treatment concentrations

\begin{tabular}{|c|c|c|c|c|c|c|c|c|c|c|c|}
\hline \multirow{2}{*}{ Time $(d)$} & \multicolumn{5}{|c|}{ Alachlor $(\mu \mathrm{g} / \mathrm{L})$} & \multicolumn{6}{|c|}{ Chlorophyll $a\left(\mathrm{mg} / \mathrm{m}^{2}\right)$} \\
\hline & \multicolumn{5}{|c|}{ Nominal concentration $(\mu \mathrm{g} / \mathrm{L})$} & \multicolumn{6}{|c|}{ Treatment concentration $(\mu \mathrm{g} / \mathrm{L})$} \\
\hline Pretreatment & ND & ND & ND & ND & ND & 5.52 & 6.73 & 7.36 & 6.57 & 5.52 & 7.32 \\
\hline $3 \mathrm{~h}$ & 0.89 & 9.0 & 27.2 & 84.9 & 989.9 & - & - & - & - & - & - \\
\hline 1 & 0.66 & 6.2 & 19.5 & 47.6 & 1027 & 7.65 & 7.82 & 4.81 & 5.27 & 4.14 & 44.1 \\
\hline 14 & 0.14 & 1.10 & 2.3 & 5.46 & 305.7 & 13.4 & 11.0 & 8.11 & 6.27 & 9.70 & 9.16 \\
\hline 21 & ND & 0.04 & 0.70 & 2.81 & 240.6 & 21.1 & 16.7 & 7.86 & 6.52 & 10.9 & 9.66 \\
\hline
\end{tabular}

ND $=$ Not detected

$\mathrm{L}$ acid-cleaned and hexane-rinsed amber glass bottles into the center of the stream tanks in the channel opposite the paddle-wheel. Water samples were then analyzed for the presence of alachlor by gas chromatography. Extraction of alachlor from the water was achieved using 3M Empore Extraction discs (Varian, Harbor City, CA, USA). The extracted alachlor was eluted from the discs in ethyl acetate. Samples were concentrated under nitrogen and analyzed with a Shimadzu model 14-A gas chromatograph (Kyoto, Japan), with a ${ }^{63} \mathrm{Ni}$ electron capture detector, $\mathrm{N}_{2}$ flowing at $2 \mathrm{ml} / \mathrm{min}$, using a 30-m RTX-1 glass capillary column. The limit of detection was $0.001 \mu \mathrm{g} / \mathrm{L}$ alachlor. Standards were made from $98 \%$ pure alachlor (ChemService, West Chester, PA, USA).

Algal samples were collected by randomly selecting two 5$\mathrm{cm}$ square tiles from each stream. Tiles were gently removed from the stream with large forceps and all algae were scraped from the tile with a razor blade into a $100-\mathrm{mL}$ glass collection jar. Two tiles were chosen at random on each sampling date. To one of the algal samples, a 1\% Lugol's iodine preservative solution was added for cell counts. Algae were identified (dominant taxa were identified to genus or species) and/or counted with a Palmer cell (Wildco, Saginaw, MI, USA) and a Whipple grid, on an Olympus model FH compound microscope, at $400 \times$ magnification. The other algal sample was immediately filtered onto a Whatman GF/C glass microfiber filter for chlorophyll $a$ analysis, using the $90 \%$ ethanol extraction method of Sartori [22], and scanned on a Lambda-3B spectrophotometer (Perkin-Elmer, Norwalk, CT, USA).

Water samples for total phosphorus, total nitrogen, as well as dissolved oxygen and temperature measurements were collected prior to treatment, midway through the experiment (10 d), and at the end of the study (21 d).

Table 2. Summary of water quality parameters measured weekly during the study period (standard deviations in parentheses)

\begin{tabular}{lcccc}
\hline & $\begin{array}{c}\text { Pretreat- } \\
\text { ment }\end{array}$ & Week 1 & Week 2 & Week 3 \\
\hline D.O. $(\mathrm{mg} / \mathrm{L})$ & 11.2 & 10.4 & 9.9 & 10.2 \\
& $(0.33)$ & $(0.44)$ & $(0.40)$ & $(0.30)$ \\
Total N $(\mathrm{mg} / \mathrm{L})$ & 1.465 & 1.278 & 1.553 & 0.929 \\
& $(0.26)$ & $(0.19)$ & $(0.20)$ & $(0.15)$ \\
Total P $(\mathrm{mg} / \mathrm{L})$ & 0.039 & 0.048 & 0.086 & 0.042 \\
& $(0.01)$ & $(0.01)$ & $(0.01)$ & $(0.02)$ \\
Temperature $\left({ }^{\circ} \mathrm{C}\right)$ & 10.2 & 9.8 & 9.9 & 10.1 \\
& $(0.11)$ & $(0.15)$ & $(0.19)$ & $(0.14)$ \\
\hline
\end{tabular}

\section{Pesticide addition}

Alachlor was introduced on December 21, 1992 into the streams as a liquid (Confidence $\AA, 45.1 \%$ a.i.) in double-distilled, deionized water, at six nominal concentrations $(0,1,10,30,100$, and $1,000 \mu \mathrm{g} / \mathrm{L}$ ), applied in a randomized complete block design. These concentrations were chosen to equal or exceed levels known to affect algae (based on previous reports), as well as levels known to occur in stream environments in the midwestern U.S. Water and algal samples were collected as described prior to treatment, then at $1,3,7,14$, and $21 \mathrm{~d}$ after herbicide addition. These collection dates were selected to detect both shortand long-term effects on the algae and to avoid even longer-term "container effects" inherent in microcosm systems. An additional water sample for alachlor analysis was collected at $3 \mathrm{~h}$.

\section{Data analyses}

Chlorophyll $a$ and alachlor data were analyzed with an ANOVA with repeated measures. Cell density data were analyzed with a split-plot ANOVA with all analyses performed using SAS [23]. Overall treatment effects over time were observed for chlorophyll $a$, alachlor, and for each dominant alga or group of algae, as well as between treatment effects, using a 95\% level of confidence. One replicate $(0 \mu \mathrm{g} / \mathrm{L}$ alachlor) was not used after day 3 , due to water leakage through the plastic liner.

\section{RESULTS}

Alachlor concentrations in the water column $3 \mathrm{~h}$ after addition were near target levels (measured levels in parentheses): $1 \mu \mathrm{g} / \mathrm{L}$ (0.89), $10 \mu \mathrm{g} / \mathrm{L}$ (9.0), $30 \mu \mathrm{g} / \mathrm{L}$ (27.2), $100 \mu \mathrm{g} / \mathrm{L}$ (84.9), 1,000 $\mu \mathrm{g} / \mathrm{L}$ (989.9). Concentrations of alachlor present in the water generally decreased over the 21-d study period (Table 1). In the 1,000- $\mu \mathrm{g} /$ $\mathrm{L}$ treatment, the level of alachlor remaining in the water after 21 $\mathrm{d}$ was $240.6 \mu \mathrm{g} / \mathrm{L}$, while the $100-\mu \mathrm{g} / \mathrm{L}$ treatment had $2.8 \mu \mathrm{g} / \mathrm{L}$ remaining after $21 \mathrm{~d}$. All other treatment concentrations dropped to levels below $1.0 \mu \mathrm{g} / \mathrm{L}$ by $21 \mathrm{~d}$. Alachlor was not detected in control channels. No significant changes were observed throughout the study for total phosphorus, total nitrogen, dissolved oxygen, or temperature; thus, these parameters are presented as mean values for the entire study period (Table 2).

\section{Community-level effects}

Chlorophyll a. Chlorophyll $a$ was significantly reduced at all alachlor concentrations except at the $1.0-\mu \mathrm{g} / \mathrm{L}$ level (Table 1). 
Table 3. Algal divisions found and their corresponding dominants (all algae found in sufficient numbers to be statistically analyzed)

\begin{tabular}{|c|c|c|}
\hline $\begin{array}{l}\text { Chlorophyta } \\
\text { (green algae) }\end{array}$ & $\begin{array}{l}\text { Bacillariophyta } \\
\text { (diatoms) }\end{array}$ & $\begin{array}{c}\text { Cyanophyta } \\
\text { (blue-green algae) }\end{array}$ \\
\hline $\begin{array}{l}\text { *Ankistrodesmus falcatus } \\
\text { *Scenedesmus spp. } \\
\text { *Crucigenia tetrapedia } \\
\text { Dictyosphaerium pulchellum } \\
\text { Unicellular } \\
\text { Colonial } \\
\text { *Filamentous }\end{array}$ & $\begin{array}{l}\text { Synedra spp. } \\
\text { *Nitzschia spp. } \\
\text { Fragilaria crotonensis } \\
\text { * Melosira varians } \\
\text { Centric diatoms }\end{array}$ & $\begin{array}{l}\text { Unicellular } \\
\text { Colonial }\end{array}$ \\
\hline
\end{tabular}

Chlorophyll $a$ declined sharply at higher concentrations for approximately $3 \mathrm{~d}$, rebounded by $7 \mathrm{~d}$, and then remained relatively constant, although never reaching control levels. Levels in the control and $1.0-\mu \mathrm{g} / \mathrm{L}$ treatment tanks gradually increased to $21 \mathrm{~d}$, again indicating no detectable effects at the $1.0-\mu \mathrm{g} / \mathrm{L}$ concentration. There were no significant differences in chlorophyll $a$ levels among the 10-, 30-, 100-, and 1,000- $\mu \mathrm{g} / \mathrm{L}$ treatments.

Total cell density. Total cell densities increased over time at all concentrations; however, cell densities remained lower at the $30-, 100-$, and $1,000-\mu \mathrm{g} / \mathrm{L}$ treatments. There was a significant decrease in total cell density at $3 \mathrm{~d}$ and $7 \mathrm{~d}$ in all but the $1.0-\mu \mathrm{g} / \mathrm{L}$ concentrations, followed by a recovery and gradual increase to $21 \mathrm{~d}$. No significant differences were found between the controls, the $1.0-\mu \mathrm{g} / \mathrm{L}$, and the $10.0-\mu \mathrm{g} / \mathrm{L}$ treatments (Figure 2).

\section{Species effects}

The effects of the alachlor exposure over time varied considerably among algal taxa. The effects of the five different alachlor concentrations also varied widely for each taxon (Figures 3-5). Alachlor had a significant inhibitory effect on the green algae Ankistrodesmus falcatus (Corda) Ralfs $(p=0.0001)$, Scenedesmus spp. ( $p=0.008)$, Crucigenia tetrapedia (Kirch.) W.\&G.S.
West $(p=0.003)$, the diatoms Nitzschia spp. $(p=0.044)$ and Melosira varians Ag. $(p=0.024)$, green algal filaments $(p=0.042)$, and colonial green algae $(p=0.051)$. Ankistrodesmus falcatus was not significantly affected by the $1.0-$ and $10.0-\mu \mathrm{g} / \mathrm{L}$ treatments but was significantly reduced at each sampling date at 30,100 , and $1,000 \mu \mathrm{g} / \mathrm{L}$. Scenedesmus spp. was not significantly affected at 1 , 10 , or $30 \mu \mathrm{g} / \mathrm{L}$ but was negatively affected at 100 and $1,000 \mu \mathrm{g} / \mathrm{L}$. Nitzschia spp. densities dropped markedly by $1 \mathrm{~d}$ at all concentrations except $1.0 \mu \mathrm{g} / \mathrm{L}$. Densities at the higher concentrations continued to be suppressed throughout the experiment, never reaching those of the control or 1.0- $\mu \mathrm{g} / \mathrm{L}$ levels. Crucigenia tetrapedia was significantly impacted at all five alachlor concentrations. Melosira varians exhibited a significant decline in all but $1.0 \mu \mathrm{g} / \mathrm{L}$, with a marked decrease in density at 30,100 , and $1,000 \mu \mathrm{g} / \mathrm{L}$ at $1 \mathrm{~d}$, followed by a gradual increase; however, no clear trend was evident because $M$. varians densities in control streams fluctuated considerably. Filamentous green algae were present in very low numbers at all concentrations, including the controls, but then increased markedly at $14 \mathrm{~d}$ and $21 \mathrm{~d}$, particularly at 100 and 1,000 $\mu \mathrm{g} / \mathrm{L}$. Colonial green algae showed a significant decline in cell density by $1 \mathrm{~d}$ at all treatment levels, with no recovery until $21 \mathrm{~d}$. Fragilaria crotonensis Kitton $(p=0.562)$, a filamentous diatom, was not significantly impacted. This species was not present un-

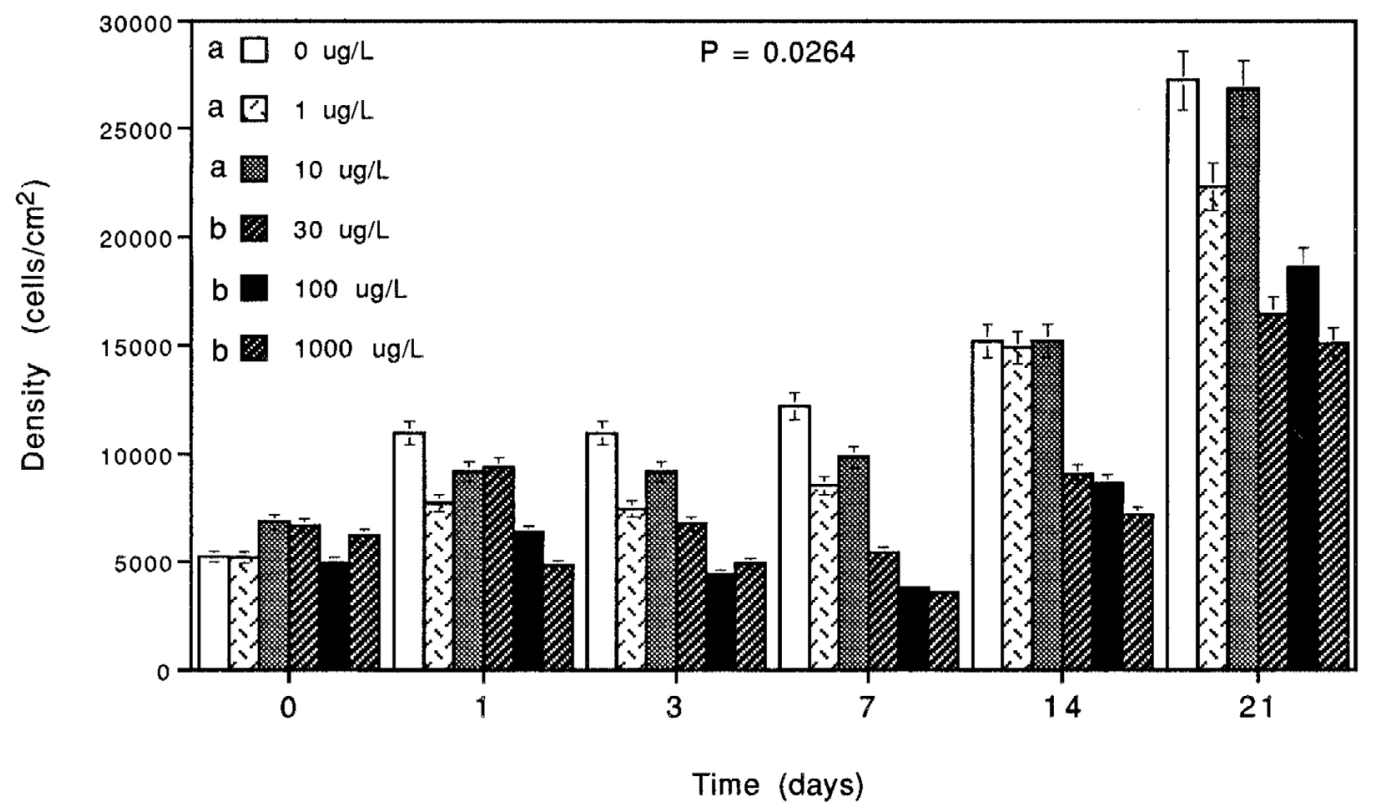

Figure 2. Total algal cell densities during the 21-d study period $( \pm$ SE). Letters in key indicate which treatments are significantly different. The $p$-value indicates the overall treatment effect. 

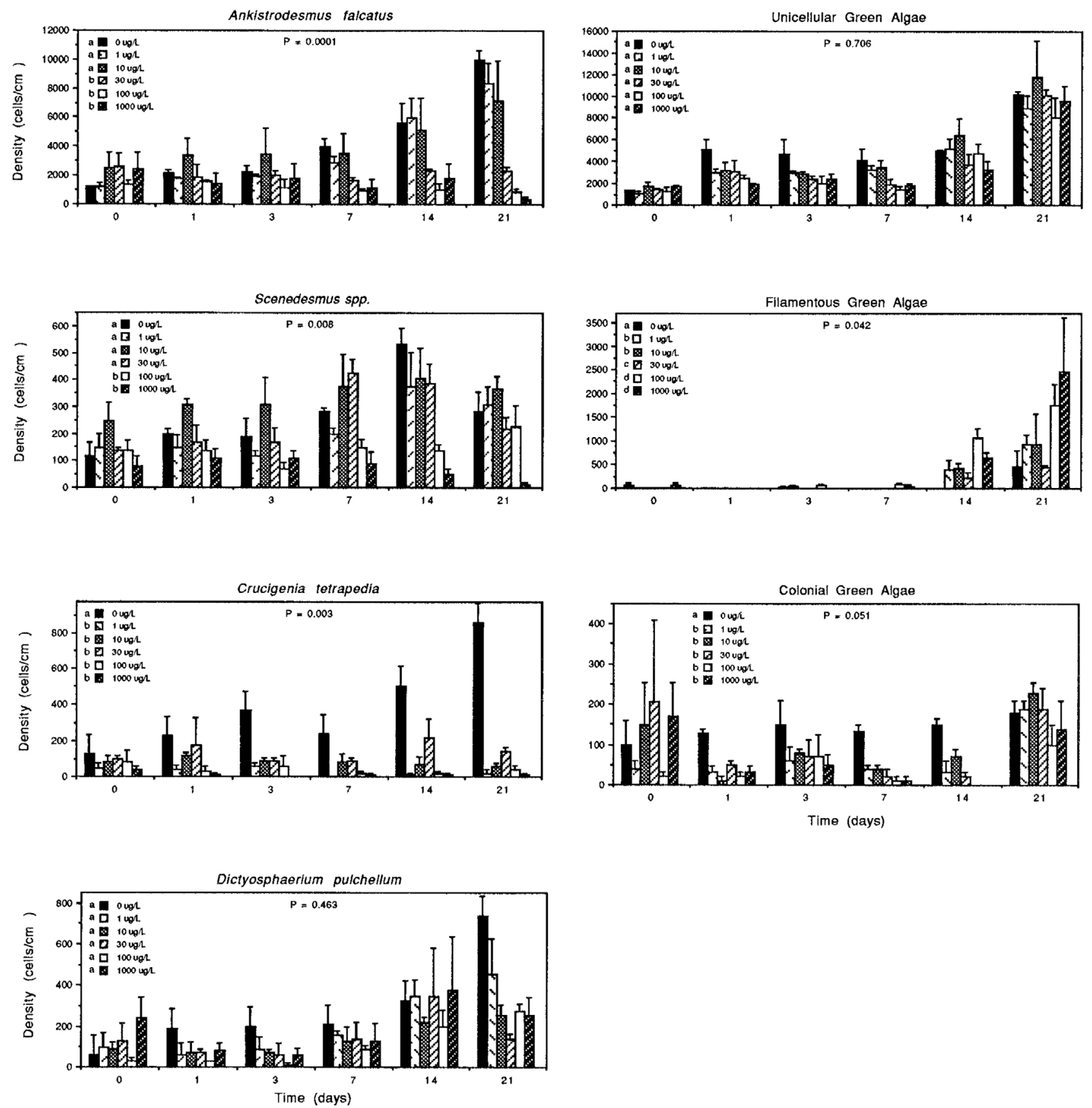

Figure 3. Cell densities during the 21-d study period $( \pm \mathrm{SE})$ for the Chlorophyta (green algae). Letters in key indicate which treatments are significantly different. The $p$-value indicates the overall treatment effect.

til the end of the study, appearing after dissipation of the herbicide. Other algae that showed no significant negative effect were Synedra spp. $(p=0.193)$, centric diatoms $(p=0.241)$, Dictyosphaerium pulchellum Wood ( $p=0.463)$, unicellular green algae ( $p=0.706)$, unicellular blue-green algae $(p=0.786)$, and colonial blue-green algae $(p=0.137)$.

\section{DISCUSSION}

\section{Alachlor concentration}

Levels of alachlor in the water column gradually decreased over time at all concentrations; however, the levels of alachlor still present in the water column after $21 \mathrm{~d}$ remained high in the $100-\mu \mathrm{g} / \mathrm{L}$ and $1,000-\mu \mathrm{g} / \mathrm{L}$ treatments. These levels were sufficient to cause a continuous inhibitory effect over the 21-d study period in the more sensitive algae (Figures $3-5$ ). The $1.0-\mu \mathrm{g} / \mathrm{L}$ treatment dropped below the level of detection by $21 \mathrm{~d}$; the $10-$ and $30-\mu \mathrm{g} /$ $\mathrm{L}$ treatments dropped below $1.0 \mu \mathrm{g} / \mathrm{L}$ by $21 \mathrm{~d}$. McGlamery and Slife [24] and Harris and Warren [25] found that alachlor readily adsorbed to soil colloids, thus decreasing levels detected in water. Because alachlor adsorbs to organic material, the toxin may have been present in the sediment, on the walls of the stream tanks, or on cell surfaces, rather than in the water column. However, alachlor concentrations remained high enough to potentially have an inhibitory effect on algae at $14 \mathrm{~d}$ in the $30-, 100-$, and $1,000-\mu \mathrm{g} /$ 
Figure 4. Cell densities during the 21-d study period $( \pm \mathrm{SE})$ for the Bacillariophyta (diatoms). Letters in key indicate which treatments are significantly different. The $p$-value indicates the overall treatment effect.
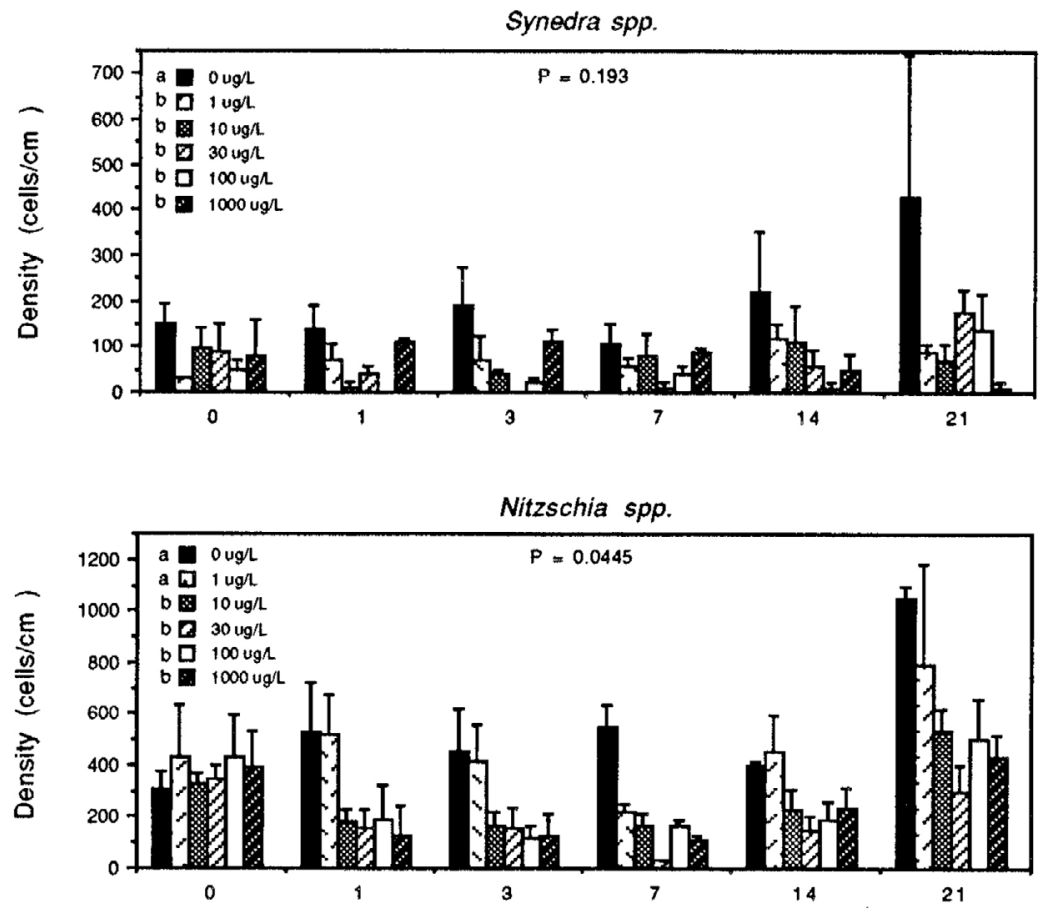

Fragilaria crotonensis
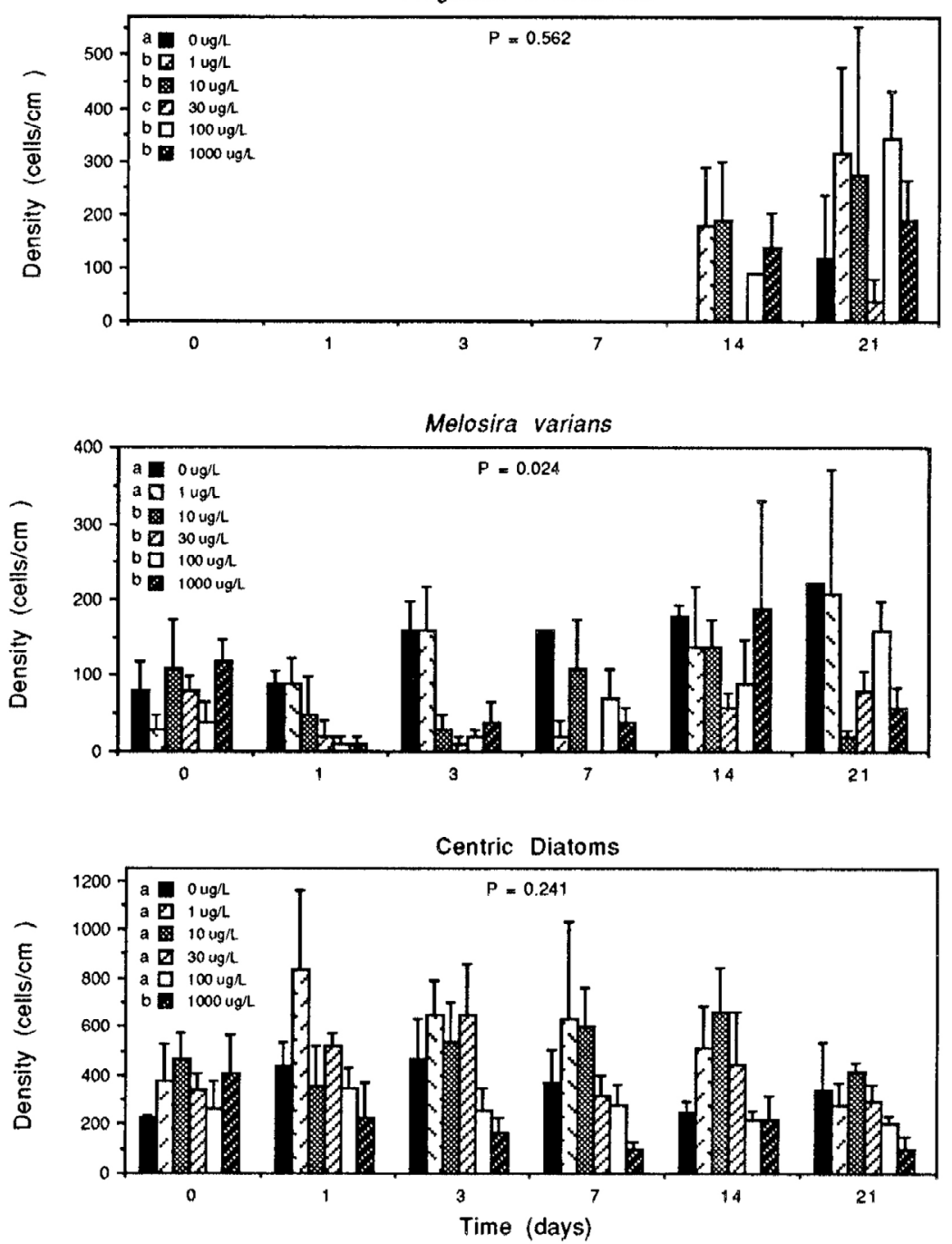

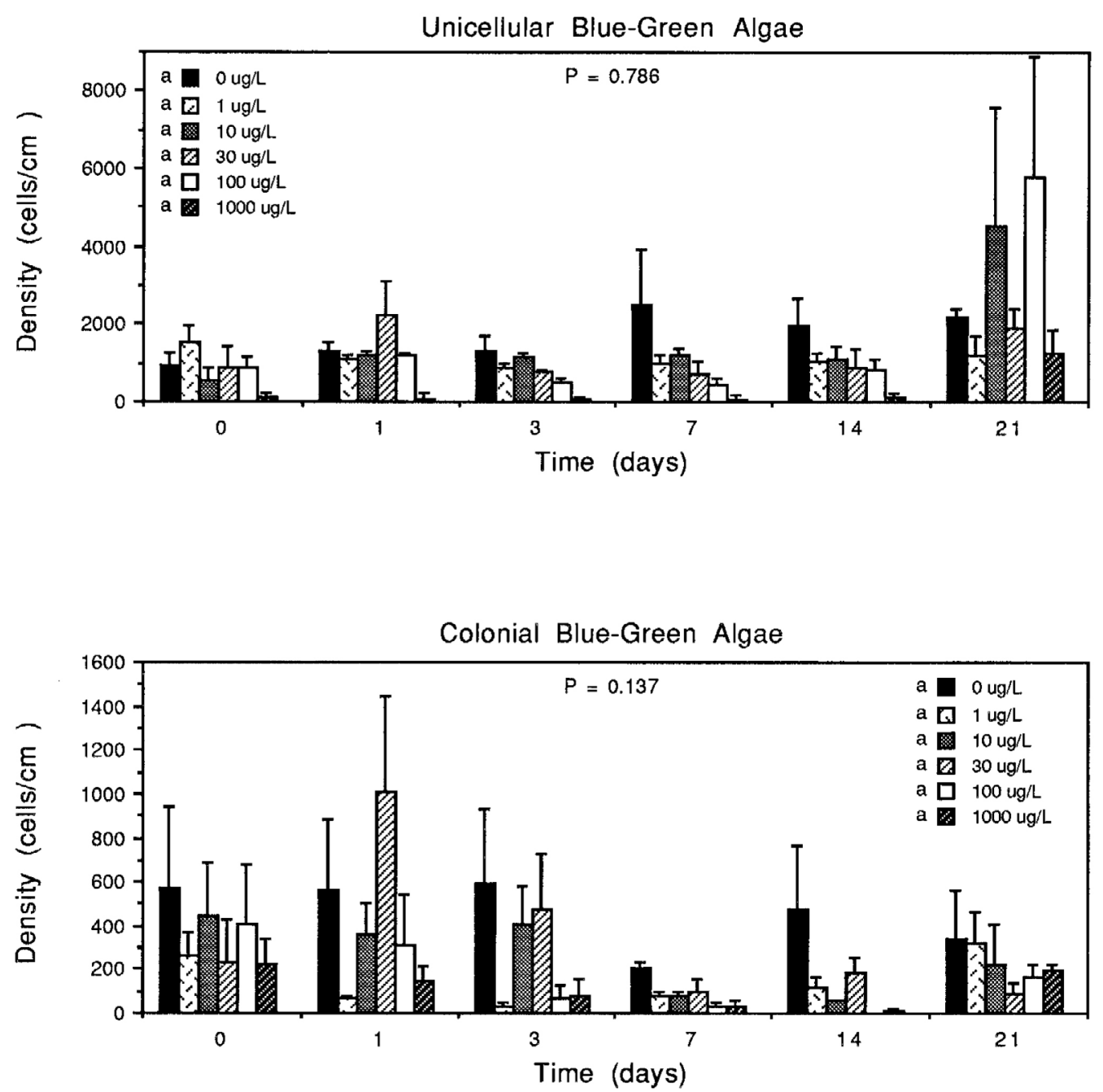

Figure 5. Cell densities during the 21-d study period $( \pm \mathrm{SE})$ for the Cyanophyta (blue-green algae). Letters in key indicate which treatments are significantly different. The $p$-value indicates the overall treatment effect.

L treatments. A pulse of alachlor is common in many agricultural streams during a storm runoff event [3]. Therefore our single pulse treatment was a reasonable mimic of environmentally realistic conditions. Furthermore, the 21-d exposure duration with subsequent declining alachlor concentrations is consistent with the 15-d hydrolysis half-life of alachlor [26].

\section{Community-level effects}

Chlorophyll $a$. Chlorophyll $a$ biomass was significantly reduced at $\geq 10 \mu \mathrm{g} / \mathrm{L}$ alachlor in the present study. Few studies have investigated the effects of alachlor on algal community biomass. However, many similar studies have shown decreases in productivity, biovolume, and photosynthesis at varying concentrations of other herbicides. Declines in chlorophyll $a$ and algal biomass were found by Krieger et al. [15] at $134 \mu \mathrm{g} / \mathrm{L}$ atrazine. Hamala and Kollig [27] reported a marked decrease in algal density in artificial streams exposed to $100 \mu \mathrm{g} / \mathrm{L}$ atrazine; Hamilton et al. [28] found a reduction in lentic algal productivity of 21 to $82 \%$ at 800 to $1,560 \mu \mathrm{g} / \mathrm{L}$ atrazine and Herman et al. [29] found a 36 to $67 \%$ decrease in chlorophyll $a$ and total biomass for attached algae.
Chlorophyll $a$ as a biomass indicator can be misleading, because effects on individual taxa are not evident. For example, cell densities for the dominant alga in this community, A. falcatus, were lower in the $1.0-\mu \mathrm{g} / \mathrm{L}$ streams than in the controls ( $p=0.0001$ ), suggesting that this species is extremely sensitive to alachlor. However, the decrease in chlorophyll $a$ resulting from a decline in A. falcatus was masked by increases in chlorophyll $a$ resulting from concomitant increases in the more tolerant algae.

Total cell density. Total cell density increased over time for all treatment levels; however, cell densities increased considerably less at the 30-, 100-, and 1,000- $\mu \mathrm{g} / \mathrm{L}$ concentrations, indicating growth inhibition of the algal community. Alachlor inhibits growth by interfering with starch mobilization, lipid synthesis, and by causing intracellular membrane damage [10]. Therefore, it is reasonable that a decrease in cell density would be seen early in the study ( $3 \mathrm{~d}$ and $7 \mathrm{~d}$ ), followed by a gradual increase in cell densities as levels of alachlor decreased over time. DeNoyelles et al. [12] studied the impact of atrazine on plankton in experimental ponds and found an initial decrease in algal biomass, followed by recovery after $7 \mathrm{~d}$. Several other previous studies have shown similar algal responses to herbicides [30-32]. 


\section{Species effects}

There is evidence to suggest that algal sensitivity to herbicides can differ widely among taxa [33]. Algal responses to the herbicide atrazine, for example, vary widely depending upon concentrations used, duration of exposure, and algal species tested. Jurgensen and Hoagland [34] found short-term pulses of atrazine had no effect on in situ-attached stream algae at $\sim 100 \mu \mathrm{g} /$ L. Lynch et al. [35] found no significant atrazine effects on attached algal biomass, primary productivity, or community respiration at $25 \mu \mathrm{g} / \mathrm{L}$, with $30-\mathrm{d}$ exposure durations. Goldsborough and Robinson [36] found no significant decrease in total algal biovolume with short exposures of $100 \mu \mathrm{g} / \mathrm{L}$ of the related herbicide simazine. In contrast, Butler et al. [37] found atrazine concentrations as low as $10 \mu \mathrm{g} / \mathrm{L}$ to have an inhibitory effect on 36 axenic isolates. Because some organisms have much greater sensitivity than others, a whole community study examining the effects among algal taxa may better serve to elucidate whole community responses and possible indirect effects.

In this study, the effects of alachlor also differed considerably among algal divisions (Figures 3-5). From these data we can determine which species were directly impacted by the herbicide; however, it is more difficult to determine relative levels of tolerance among the more resistant taxa because of the potential for indirect effects (e.g., reduced competition for nutrients and space). The marked increase in cell densities of filamentous green algae and F. crotonensis by $14 \mathrm{~d}$ at all concentrations of alachlor may have been only partially related to alachlor tolerance. A drop in cell density at 1,3 , and $7 \mathrm{~d}$ was observed for unicellular green algae (e.g., A. falcatus) and blue-green algae but was then followed by a rapid increase in cell densities near to and in some cases greater than those of the controls. It should be noted that these algal genera are generally considered planktonic; however, they also can be pseudoperiphytic (substrate associated, but not attached). The filamentous, centric diatom $M$. varians was significantly affected by alachlor; however, other centric diatoms were not significantly impacted, demonstrating that even very similar taxa can exhibit different responses to alachlor.

Environmental regulation of pesticides remains largely determined by single species toxicity tests, despite the fact that mesocosm bioassays containing natural communities have been developed to evaluate community-level impacts of toxicants [38]. Stay et al. [39] demonstrated that microcosms containing natural species assemblages rather than mixed stock monocultures more accurately reflected ecosystem-level effects of herbicides. It has been found that community-level bioassays provide important information on realistic toxicant impacts and on indirect effects that result from complex species interactions. Such information greatly enhances our ability to extrapolate results to natural aquatic systems $[12,40]$.

\section{Acknowledgments}

Our thanks to Ben Gawne, Art Popp, Mahesh Sookram, Justin Carder, Marian Langan, Bobbi Chapman, John Holz, and Monte Kukshausen for their help in the field and for assisting in the stream assembly. Dean DeNicola gave advice and assistance in the initial stages of this research. We also thank Lisa Johnson, Ben Gawne, Susan Jensen, and Ray Lewis for their suggestions and reviews. This research was made possible through funding provided by the University of Nebraska Water Center, and the U.S. Fish and Wildlife Service. This is Journal Series 11097 of the Agricultural Research Division at the University of Nebraska.

\section{REFERENCES}

1. Hileman B.1982. Herbicides in agriculture. Environ. Sci. Technol. 16:645A-650A.

2. Spalding R.F., and D.D. Snow. 1989. Stream levels of agrichemicals during a spring discharge event. Chemosphere. 19:1129-1140.

3. Thurman E.M., D.A. Goolsby, M.T. Meyer, and D.W. Kolpin. 1991. Herbicides in surface waters of the midwestern United States: The effect of spring flush. Environ. Sci. Technol. 25:1794-1796.

4. Ware G.W.1989. The Pesticide Book, 3rd ed. Thompson, Fresno, CA, USA.

5. Gianessi L.P.1987. Lack of data stymies informed decisions on agricultural pesticides. Resources. 89:1-4.

6. Thurman E.M., D.A. Goolsby, M.T. Meyer, M.S. Mills, M.L. Pomes, and D.W. Kolpin. 1992. A reconnaissance study of herbicides and their metabolites in surface waters of the midwestern United States using immunoassay and gas chromatography/ mass spectrometry. Environ. Sci. Technol. 26:2440-2447.

7. Chesters G., G.V. Simsiman, J. Levy, B.J. Alhajjar, R.N. Fathulla, and J.M. Harkin. 1989. Environmental fate of alachlor and metolachlor. Rev. Environ. Contam. Toxicol. 110:1-74.

8. Weisshaar H., G. Retzlaff, and P. Boger. 1988. Chloroacetamide inhibition of fatty acid synthesis. Pestic. Biochem. Physiol. 32:212-216.

9. Couderchet M., and P. Boger. 1993. Chloroacetamide-induced reduction of fatty acid desaturation. Pestic. Biochem. Physiol. 45:91-97.

10. Ebert E.1980. Herbicidal effects of metolachlor (2-chloro- $N$-[2ethyl-6-methylphenyl]- $N$-[2-methoxy-1-methlethyl] acetamide) at the cellular level in sorghum. Pestic. Biochem. Physiol. 13:227-236.

11. Hawxby K., B. Tubea, J. Ownby, and E. Basler. 1977. Effects of various classes of herbicides on four species of algae. Pestic. Biochem. Physiol. 7:203-209.

12. deNoyelles F., W.D. Kettle, and D.E. Sinn. 1982. The responses of plankton communities in experimental ponds to atrazine, the most heavily used pesticide in the United States. Ecology. 63:1285-1293.

13. Baker D.B., K.A. Krieger, and J.V. Setzler. 1981. The concentration and transport of pesticides in Northwestern Ohio rivers-1981. Technical Report Series 19. U.S. Army Corps of Engineers, Buffalo, New York, NY.

14. Singh H.N., H.R. Singh, and A. Vaishampayan. 1979. Toxic and mutagenic action of the herbicide alachlor (lasso) on various strains of the nitrogen-fixing blue-green alga Nostoc muscorum and characterization of the herbicide-induced mutants resistant to methylamine and L-methionine-DL-sulfoximine. Environ. Exp. Bot. 19:5-12.

15. Krieger K.A., D.B. Baker, and J.W. Kramer. 1988. Effects of herbicides on stream Aufwuchs productivity and nutrient uptake. Arch. Environ. Contam. Toxicol. 17:299-306. 
16. Wauchope R.D.1978. The pesticide content of surface water draining from agricultural fields - A review. J. Environ. Qual. 7:459-472.

17. Wu T.L., D.L. Correll, and H.E.H. Remenapp. 1983. Herbicide runoff from experimental watersheds. J. Environ. Qual. 12:330-336.

18. Round F.E.1981. The Ecology of Algae. Cambridge University Press, Cambridge, UK.

19. Yasuno M., Y. Sugaya, and T. Iwakuma. 1985. Effects of insecticides on the benthic community in a model stream. Environ. Pollut. 38:31-43.

20. Lamberti G.A., and V.H. Resh. 1985. Comparability of introduced tiles and natural substrates for sampling lotic bacteria, algae and macroinvertebrates. Freshwater Biol. 15:21-30.

21. Lind O.T.1988. Handbook of Common Methods in Limnology, 2nd ed. Kendall Hunt, Dubuque, IA, USA.

22. Sartori D.P.1982. Spectrophotometric analysis of chlorophyll $a$ in a freshwater phytoplankton. Technical Report TR115. Hydrological Research Institute, Pretoria, South Africa.

23. SAS Institute. 1989. SAS®/STAT User's Guide, Version 6.0, 4th ed. Cary, NC, USA.

24. McGlamery M.D., and F.W. Slife. 1966. The adsorption and desorption of atrazine as affected by $\mathrm{pH}$, temperature, and concentration. Weed Sci. 14:237-239.

25. Harris C.I., and E.R. Warren. 1964. Adsorption and desorption of herbicides by soils. Weeds. 12:120-126.

26. Chiron S., J. Abian, M. Ferrer, F. Sanchez-Baeza, A. Messeguer, and D. Barceló. 1995. Comparative photodegradation rates of alachlor and bentazone in natural water and determination of breakdown products. Environ. Toxicol. Chem. 14:1287-1298.

27. Hamala J.A., and H.P. Kollig. 1985. The effects of atrazine on periphyton communities in controlled laboratory ecosystems. Chemosphere. 14:1391-1408.

28. Hamilton P.B., G.S. Jackson, N.K. Kaushik, and K.R. Solomon. 1987. The impact of atrazine on lake periphyton communities, including carbon uptake dynamics using track autoradiography. Environ. Pollut. 46:83-103.

29. Herman D., N.K. Kaushik, and K.R. Solomon. 1986. Impact of atrazine on periphyton in freshwater enclosures and some ecological consequences. Can. J. Fish. Aquat. Sci. 43:1917-1925.
30. Brockway D.L., P.D. Smith, and F.E. Stancil. 1984. Fate and effects of atrazine in small aquatic microcosms. Bull. Environ. Contam. Toxicol. 32:345-353.

31. Kosinski R.J., and M.G. Merkle. 1984. The effect of four terrestrial herbicides on the productivity of artificial stream algal communities. J. Environ. Qual. 13:75-82.

32. Larsen D.P., F. deNoyelles, F. Stay, and T. Shiroyama. 1986. Comparisons of single-species, microcosm and experimental pond responses to atrazine exposure. Environ. Toxicol. Chem. 5:179-190.

33. Kasai F., N. Takamura, and S. Hatakeyama. 1993. Effects of simetryne on growth of various freshwater algal taxa. Environ. Pollut. 79:77-83.

34. Jurgensen T.A., and K.D. Hoagland. 1990. Effects of shortterm pulses of atrazine on attached algal communities in a small stream. Arch. Environ. Contam. Toxicol. 19:617-623.

35. Lynch T.R., H.E. Johnson, and W.J. Adams. 1985. Impact of atrazine and hexachlorobiphenyl on the structure and function of model stream ecosystems. Environ. Toxicol. Chem. 4:399-413.

36. Goldsborough L.G., and G.G.C. Robinson. 1986. Changes in periphytic algal community structure as a consequence of short herbicide exposures. Hydrobiologia. 139:177-192.

37. Butler G.L., T.R. Deason, and J.C. O’Kelley. 1975. The effect of atrazine, 2,4-D, methoxychlor, carbaryl and diazinon on the growth of planktonic algae. Br. Phycol. J. 10:371-376.

38. Jenkins D.G., R.J. Layton, and A.L. Buikema Jr. 1989. State of the art in ecological risk assessment. In J.R. Voshell, Jr., ed., Using Mesocosms to Assess the Aquatic Ecological Risk of Pesticides: Theory and Practice. Entomological Society of America, Lanham, MD, USA, pp. 18-32.

39. Stay F.S., A. Katko, C.M. Rohm, M.A. Fix, and D.P. Larsen. 1989. The effects of atrazine on microcosms developed from four natural plankton communities. Arch. Environ. Contam. Toxicol. 18:866-875.

40. Cairns J. Jr. 1983. Are single species toxicity tests alone adequate for estimating environmental hazard?Hydrobiologia. 100:47-57. 